\title{
DOI 10.26886/2520-7474.1(27)2018.4
}

\section{UDC 37.014:37.014.15}

\section{REALIZATION OF EDUCATIONAL POLICY IN SMALL CITIES OF UKRAINE}

\section{N. Lisova, PhD in Pedagogial Sciences \\ Cherkasy Regional Institute of Postgraduate Education of Pedagogical Workers, Ukraine, Cherkasy}

The author paid attention to the importance of small cities in the country, the mechanisms of implementation of educational policy in the state-public management of general secondary education in such cities of Ukraine, the management of the department of education in small cities was modernized, the legislative acts regulating its activities were submitted, as well as strategic documents, which define the conceptual guidelines for the development of general secondary education. The peculiarities of cooperation between the two components of the state and public administration for its development are considered, there were proposed some mechanisms for the implementation of educational policy at the local level.

Key words: mechanisms, educational policy, small cities, department of education, public-public administration, general secondary education.

кандидат педагогічних наук, Лісова Н. І. Державно-громадське управління: тендениії, довіра, школа / КНЗ «Черкаський обласний інститут післядипломної освіти педагогічних працівників, Україна, Черкаси

Звернено увагу на значущість малих міст в країні, розкрито механізми реалізації освітньої політики при державно-громадському управлінні загальною середньою освітою в таких містах України, модернізації управління відділу освіти в громадах малих міст, подано 
законодавчі акти, що регулюють його діяльність, а також стратегічні документи, що визначають концептуальні орієнтири розвитку загальної середньої освіти. Розглянуто особливості співпраці обох складових державно-громадського управління ї розвитком, а також запропоновано певні механізми щодо реалізації освітньої політики на місцевому рівні.

Ключові слова: механізми, освітня політика, малі міста, відділ освіти, державно-громадське управління, загальна середня освіта.

Постановка проблеми. Важливу роль відіграють механізми державно-громадського управління розвитком 3СО в малих містах України в період нового етапу розвитку суспільства, зокрема переходу його на демократичні засади. Варто звернути увагу на те, що в будьякій країні світу $є$ такі міста, які можна віднести до категорії так званих малих міст і які відіграють одну з провідних ролей у розвитку певного регіону і в цілому країни, бо у них можуть бути сформовані основний промисловий потенціал, наукові та культурні центри, упроваджуватися передові технології, втілюватися якісні стандарти життя громадян, нові послуги тощо. Одним словом, такі міста розвиваються по-своєму, їм властива відмінна від інших населених пунктів інфраструктура, склад населення, високий рівень міського самоврядування або й навпаки.

Зарубіжні й вітчизняні науковці (В. Бабаєв, Т. Барановська, О. Бойко- Бойчук, В. Глазічев, Б. Данилишин, С. Жилкіна, Н. Жунда, Г. Лаппо, К. Лінг, В. Мамонова, О. Нижник, В. Нікітін, Є. Перцик, І. Прокопенко та ін.) досліджували особливості розвитку міст взагалі, проте зазвичай малі міста залишалися поза увагою, хоча таких міст багато в Україні й проживає там майже половина всього населення.

Відмічаємо також про те, що в нових сучасних умовах система управління ЗСО в малих містах - це новий тип реалізації сучасної 
освітньої політики, так званий соціальний організм, який здатний запровадити механізми державно-громадського управління розвитком ЗСО та освітні інновації.

Мета статті: розкрити механізми державної освітньої політики в малих містах при державно-громадському управлінні.

Насамперед зупинимося на механізмах реалізації державної освітньої політики, модернізації управління відділу освіти в громадах малих міст. Учені В. Базілюк, Т. Бойченко, Л. Забродська та ін. вважають, що базисним підґрунтям визначення основ державної політики в освіті та стратегії її розвитку є: фрілософрія суспільного устрою, яка відображена в Конституції і відповідних законах про освіту, стан та перспективи розвитку економіки, науки, техніки, національної культури, здоров'я населення, демографічні процеси, особливості екосистем країни, об'єктивні фрактори й умови інтеграції держави в світовому економічному та культурно-освітньому просторі на паритетних засадах та збереженні своєї національно-духовної ідентичності [1, 26-27 ]. Якщо ж вдатися до розгляду сутності поняття «механізм», то у Великому тлумачному словнику знайдемо таку характеристику: «внутрішня будова, система чого-небудь» $[2,523]$, а в «Короткому економічному словнику» це поняття трактується так: «послідовність станів, процесів, які визначають собою які-небудь дії, явища; система, пристрій, який визначає порядок якого-небудь виду діяльності [3, 401]. Учений О. Конт розглядає його як соціальний механізм суспільства й одночасно стверджує: кожне суспільство має свій соціальний механізм, що забезпечує його виживання й розвиток [4]. Пізніше до дослідження цього питання долучилися соціологи (Г. Спенсер, Е. Дюркгейм, М. Вебер, Т. Веблен, К. Маркс, Т. Парсонс та ін.). За твердженням учених (Л. Юзькова, В. Авер'янова), механізм управління - це організація практичного здійснення державного 
управління, сукупність відповідних державних органів, організованих у систему для виконання цілей (завдань) державного управління відповідно до їх правового статусу, та масив правових норм, що регламентують організаційні засади та процес реалізації вказаними органами свого фрункціонального призначення [5].

Глобалізаційні, демократичні, інтеграційні процеси в українському суспільстві, які розпочалися з кінця XX століття, зумовили модернізацію системи управління ЗСО. У зв'язку з цим були розроблені законодавчі акти, що регулюють діяльність системи управління 3СО, стратегічні документи, що визначають концептуальні орієнтири ії̈ розвитку ( Національна програма «Освіта» ("Україна XXI століття") [6], Національна доктрина розвитку освіти [7], Національна стратегія розвитку освіти України на 2012-2021 рр.) [8]. Проте необхідно назвати новий Закон «Про освіту» [9], відповідно до його основних положень розробляється проект нового Закону «Про загальну середню освіту». Приведені у відповідність із розвитком держави повноваження суб'єктів органів місцевого самоврядування в освітній ссрері (Закон «Про місцеве самоврядування» [10]) створюються умови та відбувається становлення взаємодії державних і громадських фрорм управління освітою, з'являються можливості залучення додаткових місцевих ресурсів для розвитку всіх ланок 3СО, пробуджується інтерес до вирішення ії проблем у місцевому співтоваристві.

Одним із механізмів реалізації соціальної функції зСО $є$ формування єдиного освітнього простору. Він покликаний забезпечувати соціалізацію й виховання підростаючого покоління, враховуючи загальнолюдські цінності й цінності національної культури. Механізм сприяє перетворенню $3 \mathrm{CO}$ із відтворюючої системи в розвиваючу, яка здатна забезпечити розвиток особистості й розвиток місцевих громадських об'єднань, а також всієї громади. 
Варто наголосити й на тому, що сучасна освітня політика малого міста має сприяти розвитку місцевого самоврядування шляхом залучення широкої громадськості до управління й розвитку $3 \mathrm{CO}$, вирішувати питання діяльності освітніх навчальних закладів, тобто в дію може вступати механізм соціально-педагогічного партнерства.

Важливими завданнями органів управління освітою (відділів/управління освіти) є залучення громадськості до безпосередньої участі в контролі за реалізацією конституційних прав громадян на освіту та забезпечення фрінансових, матеріальнотехнічних, кадрових та інших умов, необхідних для відповідної діяльності установ освіти; надання адресної соціальної підтримки певним категоріям учнів, вихованців.

Зміст освітньої політики малого міста, на нашу думку, може сприяти: зближенню міського відділу освіти, громади та школи, їх тісному взаємозв'язку й взаємодії; розвитку цілісності та керованості системи міської освіти; створенню самостійних громадських структур управління; подоланню роз'єднаності місцевої громади, фрормуванню первинних осередків громадянського суспільства; підтримці інноваційних процесів і педагогічній творчості; соціалізації дітей, охороні прав і соціальному захисті дітей, а також підтримці високого статусу працівників освіти та забезпечення її інвестиціями тощо.

Освітня політика в малому місті може являти собою своєрідний єдиний, цілісний, багатопрофільний і багатофункціональний освітній комплекс, а відділ освіти покликаний стимулювати створення об'єднаних освітніх одиниць - освітніх комплексів, асоціацій, клубів та ін., школа ж має стати соціально-культурним центром громади малого міста.

Таким чином, управління міською системою освіти має будуватися на засадах державно-громадських відносин, які зможуть 
усій системі забезпечити соціоорієнтований характер. Саме такий характер шкільної освіти, у свою чергу, має ще й величезний соціально-виховний зміст та організовує цілеспрямований процес розвитку особистості, її соціально-професійне становлення.

Із метою прискорення процесів демократизації в управлінні ЗСО доречно розглядати й механізм, який здатний ініціювати й підтримувати перетворення соціально-педагогічної дійсності. Таким механізмом може слугувати державно-громадська взаємодія, яка будується на основі відкритості, повноти та достовірності інформації, взаєморозуміння та довіри. При цьому соціум визначає соціальний статус управління освітою, слугує загальним фоном його життєдіяльності; у соціумі $є$ і партнери, які необхідні для вирішення освітніх завдань. Такі відносини позитивно впливають на підвищення якості освіти, розвиток соціальних, адаптивних умінь учнів, а громадськість міста виступає джерелом ресурсів розвитку системи $3 \mathrm{CO}$.

Отож, громадське управління в системі державно-громадського розглядаємо як невід'ємний компонент системи управління освіти й важливий фактор її розвитку в умовах малого міста. У таких умовах має забезпечуватися готовність державних та відомчих суб'єктів управління до перерозподілу повноважень і відповідальності в сфері управління освітою на користь громадської складової. Внаслідок такої співпраці можуть спостерігатися деякі зміни: на міському рівні зміниться співвідношення відповідальності за результати ЗСО (що відповідає загальним принципам організації місцевого самоврядування); установляться партнерські відносини між державою й громадою в сфері розподілу освітніх послуг. На рівні освітньої установи буде заснована конструктивна взаємодія з оптимального досягнення цілей її розвитку; забезпечиться розвиток відносин між 
школою й громадою 3 питань освіти учнів; будуть сформовані відносини з питань залучення та цільового використання фрінансових ресурсів. Правда, партнерські відносини будуються не просто, не завжди суб'єкти готові до тісної співпраці, часто вони можуть носити нейтральний, а то й опозиційний характер щодо розподілу управлінських повноважень та подальшої спільної роботи. Такої ситуації боятися не треба, не варто «закривати на неї очі», не замовчувати, а шляхом конструктивного діалогу, відкритості домагатися взаємопорозуміння.

При державно-громадському управлінні шкільною освітою у малому місті варто створити координаційний орган, ним може виступити Громадська рада з освіти. Важливо до ії складу, крім представників органів управління освітою, керівників структурних підрозділів адміністрації міста, ініціативних директорів шкіл, депутатів, ввести членів батьківської громадськості, старшокласників, представників міськкому профспілок працівників освіти. Структура цієї ради має включати комісії з питань атестації педагогічних кадрів, нагород, атестації та ліцензування освітніх установ, створення безпечних умов, з охорони прав неповнолітніх дітей і осіб із числа дітей-сиріт та дітей, які залишилися без піклування батьків, із замовлення товарів і послуг для закладів освіти, з питань організації літнього відпочинку, оздоровлення та зайнятості дітей і підлітків тощо.

Механізми реалізації освітньої політики в малих містах можуть виходити за межі конкретно взятого населеного пункту, вони розширюватимуться, доповнюватимуться змістом інших об'єктів соціально- освітнього простору регіонального та національного рівнів. Дослідниця О. Тягушева у монографії «Розвиток механізмів державногромадського управління регіональною системою освіти» розкрила механізми державно-громадського управління розвитком освіти на 
регіональному рівні [11]. Ми погоджуємося з її узагальненнями, тому що окремі з них аналогічні до механізмів, які реалізуються в малих містах. Ïх можна розглядати і в рамках національного рівня. Такі зв'язки сприятимуть виконанню державних нормативно-правових актів про освіту, зокрема ЗСО, розвитку державно-громадського управління якістю 3СО, організовуватимуть прогнозування розвитку міської, регіональної систем освіти як складових національної, проводитимуть регуляторно-коригуючу діяльність освітніх установ, роботу з кадрами (формування замовлення на підготовку кадрів; організація підвищення кваліфрікації педагогічних і керівних кадрів; призначення й звільнення їх; матеріальне й моральне стимулювання, нагородження); організовуватимуть соціальний захист педагогічних кадрів тощо.

У малих містах обласного підпорядкування органи державного управління освітою представлені міськими відділами або управліннями, у підпорядкуванні яких знаходяться навчальні заклади дошкільної, загальної середньої та позашкільної освіти. До структури також входять методичні центри, кабінети, служби матеріальнотехнічного забезпечення. Саме така освітня система здатна запроваджувати у містах обласного підпорядкування освітню політику, змістом діяльності якої $\epsilon$ також проведення освітніх реформ. Суб'єктами цих процесів виступають органи державної влади та міського самоврядування, які, використовуючи різні методи управління, впливають на результати освітніх реформ. Міському відділу освіти варто враховувати організаційний механізм управління цим процесом. Вважаємо, що для цього насамперед потрібно правильно розподілити функції, визначити відповідальність суб'єктів освітньої політики; не порушити підпорядкування навчальних закладів відповідним відомствам, які $є$ співзасновниками; враховуючи вимоги нормативноправової бази, залучити до участі проведення рефрорм у місті окремі 
сім'ї, роботодавців, громадські інститути, у процесі чого забезпечувати компетентне обговорення ходу реалізації реформ. На нашу думку, до структури організаційного механізму впровадження освітніх реформ необхідно включити й представників від громадськості, оскільки у державно-громадському управлінні розвитком 3СО громади відіграють важливу роль. Як свідчить досвід, лише в умовах розвинутої демократії за дієвої участі механізмів стримувань і противаг можуть вільно й ефрективно взаємодіяти влада та громада. Участь громад у відкритому управлінні впровадженням освітніх реформ $є$ свідченням того, що здійснюється незалежний нагляд за діяльністю міських органів влади, створюються умови вільного доступу до інформації, одночасно забезпечується реалізація освітньої політики.

Відділ освіти, співпрацюючи з громадськістю, має виступати в ролі посередника в державно-громадському управлінні, бути так званим механізмом гармонізації соціальних інтересів, різних фрорм конструктивного діалогу між громадою, органами міського самоврядування та владою. Органи ж державної влади зацікавлені в продуктивній співпраці з громадами різних рівнів, свідченням цього $€$ прийняті Верховною Радою закони України «Про внесення змін до деяких законодавчих актів України у зв'язку з прийняттям закону України «Про інфрормацію» (у новій редакції) та закону України «Про доступ до публічної інформації» [12].

Цінність освітніх рефрорм на сучасному етапі розвитку ЗСО проявляється в тому, що одночасно із впровадженням їх відбуваються модернізаційні процеси управління освітою, які, у свою чергу, $\epsilon$ адекватними до суспільства з ринковими відносинами та забезпечують ефективність управління 3СО. Упроваджуючи реформу ЗСО в життя, треба, по-перше, враховувати особливості попереднього й сучасного стану розвитку 3СО, зарубіжного досвіду, його трансформаційні 
ознаки, специфріку малого міста, ментальність жителів міської громади та інші фрактори; по-друге, рефрорма має базуватися на принципах і механізмах, які притаманні країнам з ринковою економікою, що, у свою чергу, забезпечить інтегрування вітчизняної системи освіти в європейський освітній простір.

Найважливішим принципом управління освітніми реформами на міському та на рівні загальноосвітнього навчального закладу повинен бути принцип системності. Тому представники органів влади в цілому та органів управління освітою зокрема повинні володіти науковими методами й технологіями управління, тобто бути професіоналами в цій сфрері. Як визначає вчена С. Калашникова, профресіоналізація управління має розглядатися як «процес, метою якого $є$ підвищення ефрективності управління шляхом вдосконалення професійного рівня управлінців, розроблення, запровадження та модернізація інструментів управління у формі відповідних методів, засобів чи технологій; фрормування світогляду у фрормі фрілософрії управління (поняття, принципи, методологія) задля наявності необхідних орієнтирів (принципів) щодо реалізації самого управління» $[13,39]$

Результати проведення освітніх реформ залежать від фрінансових та людських ресурсів, адже має функціонувати управління реформами, яке включатиме в себе механізми корегування та об'єктивної оцінки. Це сприятиме повнішому забезпеченню реалізації міської освітньої політики та підвищуватиме її ефективність. Отже, управління міською системою ЗСО має бути компетентним, демократичним, мати стратегічне завдання й лише після цього розглядатися як соціально ефективне.

Також для реалізації завдань освітньої політики в місті неабияке значення має керівник відповідної структури, очолювати відділ освіти повинен, на наше переконання, підготовлений, компетентний фахівець. 
Оскільки відділ освіти входить до складу виконкому міської ради, тому посада начальника відділу освіти віднесена до посад служби в органах місцевого самоврядування відповідно до законів України «Про державну службу» та «Про службу в органах місцевого самоврядування» [14;15]. Начальник міського органу управління освітою має чітко визначені повноваження й відповідний статус та ранг у системі державного чи самоврядного управління.

Галузь освіти в основі своїй - консервативна (так вважає не один дослідник - науковець чи практик), але у зв'язку із змінами, які відбуваються в суспільному розвитку держави, вона залучена до процесів, які охоплюють усі сфрери життєдіяльності країни. Будь-яке оновлення на державному рівні обов'язково поширюється й на місцевий рівень, точніше кажучи, усі реформи беруть початок з окремо взятих територій, у тому числі - малих міст. Інноваційні процеси, як свідчить практика, проявляють різний вплив при впровадженні їх: сприйнятливість до інновацій залежить від особистих та психологічних характеристик міських еліт, структури управління, що склалася в місті, соціального, політичного та економічного типу взаємодії впливових суб'єктів розвитку.

Одночасно варто зауважити, що певні зміни, які ввійшли в освітню практику, мають і негативний відтінок. Трапляються випадки, коли освіта поглиблює соціальну й інтелектуальну нерівність, стає дієвим інструментом суспільного розшарування, коли соціальноматеріальний статус дитини та рівень їі розвитку стає перепусткою до навчальних закладів, які забезпечують якіснішу освіту порівняно 3 іншими закладами. Тому варто запровадити такий механізм в освітній політиці міста, який би знівелював хибний підхід, а то й ліквідував такі явища, не викликав спротив у батьківській громадськості. Завдання 
відділу освіти створити умови для рівного доступу кожної дитини до якісної ЗСО.

Серед системи механізмів реалізації освітньої політики в малих містах можна виокремити й механізм оцінювання. Запровадження його сприяє: корегуванню самого процесу освітньої політики, активізації участі в управлінні ЗСО громадських організацій, забезпеченню якісних освітніх послуг, створенню умов для фрормування та реалізації освітньої політики через дискусію та діалог. Учена Л. Гриневич свого часу як голова Комітету з питань науки й освіти Верховної Ради України стверджувала, що вітчизняна освітня статистика не розкриває всі аспекти функціонування системи освіти та не надає можливості повноцінного аналізу їі стану. Виходячи 3 цього, доцільно було б вивчити досвід використання освітніх індикаторів у міжнародних порівняннях освітніх систем та скористатися його позитивними аспектами для розвитку освітньої статистики в Україні. Варто зазначити, що нещодавно Міністерством освіти і науки України подано перелік національних індикаторів ефективності та якості загальної середньої освіти [16]. Переконані, що використання їх дасть можливість управлінцям сприймати освіту з позицій міжнародних освітніх тенденцій, усвідомлено фрормувати відповідну державну політику та об'єктивно оцінювати результати її впровадження не лише на всеукраїнському рівні, а й на місцевому.

Висновки. Досліджуючи систему механізмів реалізації освітньої політики в малих містах, робимо такі висновки: по-перше, діяльність відділу освіти регламентовано нормативно-правовою базою, зокрема: законами України, директивними документами центральних органів влади, а також рішеннями колегій, наказами та інструктивними матеріалами регіональних адміністративних органів; по-друге, наявність такої законодавчої бази, що регламентує діяльність усіх 
ланок управління й закладів, які забезпечують реалізацію стратегії державної освітньої політики, має сприяти розвитку творчої ініціативи керівників і виконавців; по-третє, відділ освіти $є$ важливою ланкою у вирішенні завдань щодо реформування ЗСО та модернізації їі управління; по-четверте, доречне застосування комплексу механізмів державно-громадського управління забезпечує відповідний рівень змісту освітньої політики в малих містах, а ефективне впровадження освітньої політики залежить від модернізації усіх управлінських механізмів відділу (управління) освіти; по-п'яте, і найосновніше, впровадження державної освітньої політики вимагає від керівників відділів (управлінь) освіти належного професіоналізму, компетентності, високих морально-етичних якостей, духовності, загальної й управлінської культури, володіння сучасними управлінськими технологіями.

\section{תimepamypa:}

1. Аналіз освітньої політики: теорія і практика управління на місцевому рівні: наук. посіб. / авт. кол.: В. Г. Базілюк, Т. Є. Бойченко, Л. М. Забродська [та ін.]; Держ. вищ. навч. заклад «Ун-m менедж. освіти». - К.: Вид-во ДВНЗ «Ун-m менеджменту освіти» НАПН України, 2014. - с.306

2. Великий тлумачний словник сучасної української мови / уклад. I гол. ред. В. Т. Бусел. - К. - Ірпінь: ВТФ “Перун”, 2004. - 1440 с.

3. Краткий экономический словарь / Под ред. А. Н. Азрилияна.- М.: Институт новой экономики, 2001. - 1088 с.

4. Конт О. Загальний огляд позитивізму / пер. з фрр. І. А. Шапіро; під ред. Е. Л. Радлова. 2-е вид-во. М .: ЛИБРОКОМ, 2011. 
5. Державне управління в Україні: навч. посібн. / За заг. ред. В.Б. Авер'янова. - К.: Юрінком Інтер, 1998. - 432с. [Електронний ресурс] Режим доступу: http://www.lawbook.by.ru/admin/averjanov/2-2.shtml.

6. Державна національна програма “Освіта” (“Україна XXI столітmя”). - К.: Радуга, 1994. - 61 c.

7. Національна доктрина розвитку освіти України // Нормативноправове забезпечення освіти: у 4 ч. - Х., 2004. - 4.1. - С. 5-24.

8. Національна стратегія розвитку освіти до 2021 року [Електронний ресурс]. - Режим доступу: http://pon.org.ua/novyny/1587uryad-sxvaliv-nacionalnu-strategiyu-rozvitku.html

9. Закон України «Про освіту» [Електронний ресурс]. - Режим доступу: http://zakon4.rada.gov.ua/laws/show/651-14.

10. Закон України «Про місцеве самоврядування в Україні» [Електронний ресурс]. - Режим доступу: http://zakon.rada.gov.ua/cgibin/laws/main.cgi?nreg=280 \%2F97-\%E2 \%FO.

11. Тягушева О.В. Розвиток механізмів державно-громадського управління регіональною системою освіти: автореф. дис. на здобуття наук. ступеня канд. наук з держ. упр.: спец. 25.00 .02 «Механізми державного управління» / О. В. Тягушева. - Запоріжжя, 2009. -22 c.

12. Закон України «Про внесення змін до законодавчих актів з питань загальної середньої та дошкільної освіти щодо організації навчальновиховного процесу» [Електронний ресурс]. - Режим доступу: http://zakon2.rada.gov.ua/laws/show/2442-17.

13. Калашнікова C. A. Освітня парадигма професіоналізації управління на

засадах лідерства: [моногр.] / С. А. Калашнікова; Київ. ун-т ім. Б. Грінченка. - К.: [Київ. ун-т ім. Б. Грінченка], 2010. - 390 с. 
14. Закон України «Про державну службу» [Електронний ресурс]. Режим доступу: http://zakon5.rada.gov.ua/laws/show/889-19

15. Закон України «Про службу в органах місцевого самоврядування» [Електронний ресурс]. - Режим доступу: http://www.vinrada.gov.ua/zakon_pro_sluzbu_v_organah_miscevogo_samo vryaduvannya.htm

16. Перелік національних індикаторів ефективності та якості загальної середньої освіти [Електронний ресурс]. - Режим доступу: http://strichka.com/article/48877693

\section{References:}

1. Educational Policy Analysis: Theory and practice of local governance:

Science. guidances. / Auth. count.: V. G. Bazilyuk, T. E. Boychenko, L. M. Zabrodska [et al.] State. HI. teach. Institution "University of manager. education. " - K: Izd SHEE "University of Management Education" NAPS Ukraine, 2014 - $p$.

2. Great Dictionary of Modern Ukrainian / way. And score. Ed. VT Busel. Kyiv - Irpen: WTF "Perun", 2004. - 1440 p.

3. Brief the Economic dictionary / Ed. AN Azrylyyana.- N.: Novaya Institute of Economics, 2001. - 1088 p.

4. O. Conte Overview positivism / lane. of French. IA Shapiro; ed. EL Radlov. 2nd ed of. M.: LYBROKOM, 2011.

5. State management in Ukraine teach. posibn. / 3a Society. Ed. VB Averyanova. - K.: Yurinkom Inter, 1998. - 432s. [Electronic resource] -Mode of access: http://www.lawbook.by.ru/admin/averjanov/2-2.shtml.

6. State national program "Education" ( "Ukraine XXI Century"). - K., Rainbow, 1994. - 61 p.

7. National Doctrine for Development of Education // Ukraine Regulatory support education: 4 h. - H., 2004 - Part 1. - P. 5-24. 
8. National Strategy for the Development of Education by 2021 [electronic resource]. - Access: http: //pon.org.ua/novyny/1587-uryad-sxvalivnacionalnu-strategiyu-rozvitku.html

9. The Law of Ukraine "On General Education" [electronic resource]. Access: http://zakon4.rada.gov.ua/laws/show/651-14.

10. Law of Ukraine "On local government in Ukraine" [Electronic resource]. Access: http://zakon.rada.gov.ua/cgi-bin/laws/main.cgi?nreg=280\% 2F97-\% E2\% FO.

11. Tyahusheva A. V. Development of mechanisms of state and public administration regional education system: Author. Dis. on competition sciences. degree candidate. Science of the state. Exercise.: Spec. 25.00.02 "Mechanisms of Governance" / Tyahusheva OV. - Zaporozhye, 2009. - 22 p.

12. Law of Ukraine "On amendments to the legislation on secondary and pre-school education on the organization of educational process" [Electronic resource]. - Access:

http://zakon2.rada.gov.ua/laws/show/2442-17.

13. Kalashnikova S. A. Paradigm professionalization of educational administration at Leadership principles: [monogram.] / S. A. Kalashnikov; Kiev. University of them. B.Grinchenko. - K. [Kyiv. University of them. B. Grinchenko], 2010. - 390 p.

14. Law of Ukraine "On civil service" [electronic resource]. - Access: http://zakon5.rada.gov.ua/laws/show/889-19

15. Law of Ukraine "On service in local government" [electronic resource]. Access:

http://www.vinrada.gov.ua/zakon_pro_sluzbu_v_organah_miscevogo_samo vryaduvannya.htm 
16. The draft list of national performance indicators and quality of secondary education [electronic resource]. - Access: http://strichka.com/article/48877693 